\title{
The relative biological potencies of retinyl palmitate and $\beta$-carotene for the milk-fed lamb
}

\author{
By O. FARUQUE* AND D. M. WALKER \\ Department of Animal Husbandry, University of Sydney, Australia \\ (Received I3 Fanuary 1969-Accepted I Fuly 1969)
}

\begin{abstract}
1. Thirty-four cross-bred newborn lambs were used. A high-protein diet (25\% protein calories) was supplemented daily with retinyl palmitate (range, $13.75-440 \mu \mathrm{g} / \mathrm{kg}$ live weight $24 \mathrm{~h}$ ), or with $\beta$-carotene (range, $68 \cdot 5-2200 \mu \mathrm{g} / \mathrm{kg}$ live weight $24 \mathrm{~h}$ ) for 2 I days.

2. Live-weight gain was not increased by supplementing the basal diet with either retinyl palmitate or $\beta$-carotene.

3. The relative weights of $\beta$-carotene and retinyl palmitate (expressed as retinol) that were required to produce equivalent concentrations of retinol in the serum varied from $5: 1$ to $25: 1$, and for the liver (retinol + retinyl esters, expressed as retinol) the ratio varied from $3: 1$ to $9: 1$.
\end{abstract}

The biological potency of $\beta$-carotene, relative to preformed vitamin $A$, is not a single standard value but is dependent on the species of animal used, the level of supplementation, the previous nutritional history of the animal and the criteria used to determine the relative potencies.

The experiment now described compares the relative biological potencies of retinyl palmitate and $\beta$-carotene for the milk-fed lamb, using as criteria the live-weight gain of the lamb and the ability to raise the blood and liver concentrations of retinol from the low levels at birth. Vitamin A activity in the serum and liver is expressed as retinol in all tables.

\section{EXPERIMENTAL}

\section{Animals and their management}

Thirty-four cross-bred newborn lambs (Border Leicester $\widehat{\sigma} \times$ Merino ) $) \times$ Dorset Horn $\delta$, were used. Pregnant ewes were confined in pens for some days before parturition and fed $a d l i b$. on a diet of 50:50 (w/w) wheaten and lucerne chaff. The newborn lambs were taken away from the ewes before they had suckled, dried and housed in individual metabolism cages. The birth weights ranged from $2 \cdot 0$ to $6 \cdot 4 \mathrm{~kg}$. The mean daily maximum and minimum temperatures in the animal house were $28^{\circ}$ and $15^{\circ}$ respectively.

The newborn lambs were given their first feed within $6 \mathrm{~h}$ of birth and, after two feeds of cow's separated colostrum (Faruque \& Walker, 1970), were allotted to their dietary treatments. Since the lambs were born over a period of several weeks, it was not always possible to balance the groups exactly as regards initial live weight and sex.

\section{Experimental design}

All lambs (fifteen males and nineteen females) were given a diet containing $25 \%$ protein calories for an experimental period of 2 I days. Three lambs (group A) were

* Present address: East Regional Laboratories, PCSIR, Dhanmondi, Dacca, East Pakistan. 
given the diet unsupplemented with either retinyl palmitate or $\beta$-carotene. The remaining thirty-one lambs were allotted at random to eight groups. Groups B-G contained two male and two female lambs. Group $\mathrm{H}$ contained one male and two females and group I one male and three female lambs. The lambs in groups B-E were given $13.75,55^{\circ}, 220$ and $440 \mu \mathrm{g}$ retinyl palmitate/kg live weight $24 \mathrm{~h}$ respectively. The lambs in groups F-I were given $68.5,275, \mathrm{I}$ roo and $2200 \mu \mathrm{g} \beta$-carotene $/ \mathrm{kg}$ live weight $24 \mathrm{~h}$ respectively.

The supplements of water-miscible retinyl palmitate and all-trans- $\beta$-carotene were given once daily in the evening feed, dissolved in the milk. The vitamin supplements and the total milk intakes were adjusted daily to allow for the increase in live weight of each lamb. The level of intake of gross energy was $210 \mathrm{kcal} / \mathrm{kg}^{0.73} 24 \mathrm{~h}$.

The significance of the differences in the liver retinol reserves between groups was estimated by an analysis of variance.

Blood samples for the estimation of serum retinol were taken from the jugular vein soon after birth and before the first feed, then at weekly intervals approximately $3 \mathrm{~h}$ after the morning feed and some $\mathrm{I} 6 \mathrm{~h}$ after supplementation with retinyl palmitate or $\beta$-carotene.

At slaughter, the liver was weighed and samples were taken for the estimation of retinol. The lambs were weighed daily $4 \mathrm{~h}$ after the morning feed and the mean daily live-weight gain was estimated by a regression analysis of the daily weights.

\section{Diets}

The composition and preparation of the experimental diet, and the supplements of vitamins and trace elements were the same as those for diet no. 2, used in the experiment of Faruque \& Walker (1970).

All lambs were dosed with I ml of a groundnut-oil solution of ro000 i.u. ergocalciferol on the 2nd day of life. Aureomycin soluble $(0.45 \mathrm{~g}$; Cyanamid of Great Britain Ltd), which contained chlortetracycline hydrochloride $(25 \mathrm{mg})$, was given daily, dissolved in the milk, to each lamb. The lambs were bottle-fed three times daily at $07.00, \mathrm{r} 4.00$ and $22.00 \mathrm{~h}$ for the first 3 days, and twice daily at 07.00 and $18.00 \mathrm{~h}$ thereafter.

Water-miscible retinyl palmitate and water-miscible all-trans- $\beta$-carotene (F. Hoffmann-La Roche and Co. Ltd) were used as the supplements.

\section{Analytical methods}

Blood and liver. Serum retinol concentrations were determined on I ml samples stored at $-20^{\circ}$ under nitrogen by a modification of the method of Bessey, Lowry, Brock \& Lopez (r946). Liver samples were stored at $-20^{\circ}$ under nitrogen and retinol was extracted by the method of Röse-Gottlieb and estimated by the Carr-Price reaction as described by Hausheer, Moor, Nobile, Mueller \& Wagner (r964). 


\section{RESULTS AND DISCUSSION}

Mean values for the intakes of energy, live weights and live-weight gains, liver weights and liver retinol reserves are given in Table $\mathrm{I}$. All lambs gained in weight throughout the experimental period. No refusals of the diet occurred and all lambs were active and keen to drink. There were no significant differences between the live-weight gains of the groups.

Table I. Mean values with their standard errors for the live weight, energy intake and live-weight gain per $24 \mathrm{~h}$, liver weight and liver retinol content of lambs given different supplements of retinyl palmitate or $\beta$-carotene

\begin{tabular}{|c|c|c|c|c|c|c|c|}
\hline Group & $\begin{array}{l}\text { No. of } \\
\text { lambs }\end{array}$ & $\begin{array}{l}\text { Supplement } \\
(\mu \mathrm{g} / \mathrm{kg})\end{array}$ & $\begin{array}{c}\text { Live } \\
\text { weight }(\mathrm{kg})\end{array}$ & $\begin{array}{c}\text { Energy } \\
\text { intake } \\
\text { (kcal) }\end{array}$ & $\begin{array}{l}\text { Live-weight } \\
\text { gain (g) }\end{array}$ & $\begin{array}{l}\text { Liver } \\
\text { weight (g) }\end{array}$ & $\begin{array}{l}\text { Retinol per liver } \\
(\mu \mathrm{g})\end{array}$ \\
\hline A & 3 & $\circ$ & $5 \cdot 3$ & 700 & 128 & 96 & $15 \pm 3$ \\
\hline \multicolumn{8}{|c|}{ Retinyl palmitate } \\
\hline B & 4 & $13 \cdot 75$ & $4^{\cdot} \cdot 9$ & 660 & I I I & 91 & $63 \pm 32$ \\
\hline C & 4 & $55^{\circ} \circ$ & $5^{\cdot I}$ & 670 & 109 & IOI & $487 \pm 51$ \\
\hline D & 4 & 220 & $5 \cdot 4$ & 700 & I 16 & 105 & $4700 \pm 286$ \\
\hline $\mathrm{E}$ & 4 & 440 & $5 \cdot 8$ & 750 & I 18 & 115 & $10800 \pm 1080$ \\
\hline \multicolumn{8}{|c|}{$\beta$-Carotene } \\
\hline $\mathrm{F}$ & 4 & $68 \cdot 5$ & $4 \cdot 7$ & 630 & II9 & $9 \mathrm{I}$ & $152 \pm 54$ \\
\hline G & 4 & 275 & $4^{\cdot 6}$ & 610 & 100 & 94 & $934 \pm 162$ \\
\hline $\mathrm{H}$ & 3 & IIOO & $5 \cdot 5$ & 670 & I I I & 95 & $5840 \pm 112$ \\
\hline I & 4 & 2200 & $4 \cdot 8$ & 650 & 96 & 95 & $8980 \pm 505$ \\
\hline $\begin{array}{l}\text { SE of } \\
\text { group } \\
\text { mean }\end{array}$ & - & 一 & \pm 0.3 & \pm 27 & \pm 5 & \pm 4 & 一 \\
\hline
\end{tabular}

Liver. Liver retinol reserves were closely related to the intake of retinyl palmitate and the differences between groups were highly significant $(P<0.01)$. The regression equations $(n=16)$, with the correlation coefficients $(r)$, residual standard deviations (RSD), and the RSD expressed as a percentage of the mean of the dependent variable were

$$
\begin{array}{ccc}
L & =0.225 I-4.87 & \\
& \operatorname{RSD}= \pm 4.5(12.5 \%) & (r=+0.99) \\
\text { or } \quad I \quad=4.39 I+23.59 \\
& \operatorname{RSD}= \pm 19.9(10.9 \%) & (r=+0.99) \\
& L_{T}=0.210 I_{T}-302 \\
& \operatorname{RSD}= \pm 293(8.7 \%) & (r=+0.99) \\
\text { or } \quad I_{T}=4.742 L_{T}+1507 \\
& \operatorname{RSD}= \pm 1359(7.7 \%) \quad(r=0.99)
\end{array}
$$

where $I=\mu \mathrm{g}$ retinyl palmitate intake $/ \mathrm{kg}$ live weight $24 \mathrm{~h}, I_{T}=$ total intake of retinyl palmitate $(\mu \mathrm{g}), L=\mu \mathrm{g}$ retinol/g liver and $L_{T}=$ total retinol per liver $(\mu \mathrm{g})$. The regressions were highly significant $(P<0 \circ 01)$. 
There were no measurable amounts of $\beta$-carotene in the livers of any of the lambs. There was a close relationship between the intake of $\beta$-carotene and the liver retinol reserves. The differences between the groups were highly significant $(P<0 \circ 01)$. The regression equations ( $n=15$ ), were

$$
\begin{aligned}
L= & 0.044 I_{C}+0.90 \\
& \operatorname{RSD}= \pm 9.3(22.7 \%) \quad(r=+0.98), \\
L_{T}= & 0.042 I_{C T}+\mathrm{IOI} \\
& \operatorname{RSD}= \pm 840(2 \mathrm{I} .8 \%) \quad(r=+0.98),
\end{aligned}
$$

where $I_{C}=\mu \mathrm{g} \beta$-carotene intake $/ \mathrm{kg}$ live weight $24 \mathrm{~h}, I_{C T}=$ total intake of $\beta$ -

\begin{tabular}{|c|c|c|c|c|c|c|c|}
\hline \multirow[b]{2}{*}{ Group } & \multirow{2}{*}{$\begin{array}{l}\text { No. of } \\
\text { lambs }\end{array}$} & \multirow{2}{*}{$\begin{array}{l}\text { Supplement } \\
(\mu \mathrm{g} / \mathrm{kg} 24 \mathrm{~h})\end{array}$} & \multicolumn{4}{|c|}{ Time of sampling (weeks) } & \multirow{2}{*}{$\begin{array}{c}\text { SE of group } \\
\text { mean }\end{array}$} \\
\hline & & & Birth & $\mathbf{I}$ & 2 & 3 & \\
\hline A & 3 & $\circ$ & $10 \cdot 8$ & $7 \cdot 5$ & $7 \cdot 8$ & $6 \cdot 0$ & \pm 0.4 \\
\hline \multicolumn{8}{|c|}{ Retinyl palmitate } \\
\hline B & 4 & 13.75 & $9 \cdot 0$ & $10 \cdot 2$ & 10.2 & 10.2 & \pm 0.4 \\
\hline C & 4 & $55^{\circ} \circ$ & $10 \cdot 2$ & $20 \cdot 4$ & $20 \cdot 7$ & $23 \cdot 4$ & $\pm 1 \cdot 0$ \\
\hline D & 4 & 220 & $9 \cdot 0$ & 19.5 & $29 \cdot 7$ & $26 \cdot 7$ & $\pm x \cdot 0$ \\
\hline $\mathrm{E}$ & 4 & 440 & $10 \cdot 4$ & $26 \cdot 7$ & $32 \cdot 4$ & $35^{\cdot I}$ & $\pm I \cdot I$ \\
\hline \multicolumn{8}{|c|}{$\beta$-Carotene } \\
\hline $\mathrm{F}$ & 4 & $68 \cdot 5$ & II 4 & $11 \cdot 4$ & $10 \cdot 8$ & $10 \cdot 8$ & $\pm 0 \cdot 1$ \\
\hline $\mathrm{G}$ & 4 & 275 & $9^{\circ} 0$ & $13 \cdot 2$ & $14 \cdot I$ & $16 \cdot 8$ & \pm 0.3 \\
\hline $\mathrm{H}$ & 3 & I 100 & $9 \cdot 3$ & $17 \cdot 1$ & $17 \cdot 4$ & 25.5 & $\pm I \cdot 2$ \\
\hline I & 4 & 2200 & $8 \cdot 4$ & $18 \cdot 6$ & $20 \cdot I$ & $29 \cdot I$ & \pm 0.8 \\
\hline
\end{tabular}
carotene $(\mu \mathrm{g}), L=\mu \mathrm{g}$ retinol $/ \mathrm{g}$ liver and $L_{T}=$ total retinol per liver $(\mu \mathrm{g})$.

Table 2. Mean values with their standard errors for the retinol content of the blood serum $(\mu \mathrm{g} / \mathrm{1} 00 \mathrm{ml})$ of lambs given different supplements of retinyl palmitate or $\beta$-carotene

Serum. The mean value for the serum retinol concentration before suckling was $9 \cdot 8 \pm 0 \cdot 4 \mu \mathrm{g} / 100 \mathrm{ml}(n=34$, range $6 \cdot 9-13 \cdot 8)$. The mean values for the serum retinol concentrations at each of the weekly sampling periods are given in Table 2.

The levels of retinyl palmitate supplementation given to lambs in groups $\mathrm{C}, \mathrm{D}$ and $E$ resulted in an increase in the serum retinol concentrations, whilst the level of supplementation given to group B was sufficient only to maintain the serum concentration at its initial value. In the unsupplemented group (group A) the serum concentration decreased slightly during the experiment.

There was a significant correlation $(P<0.0 r)$ between the retinol concentration in the serum samples taken just before slaughter and the logarithm of the retinyl palmitate intake. The regression equation $(n=16)$, was

$$
\begin{gathered}
S=14.9823 \log I-5.6 \mathrm{I} \\
\mathrm{RSD}= \pm 6.4 \quad(r=+0.82) \\
\text { or } \log I=0.0452 S+0.89 \\
\mathrm{RSD}= \pm 0.35 \quad(r=+0.82)
\end{gathered}
$$

where $I=\mu \mathrm{g}$ retinyl palmitate intake $/ \mathrm{kg}$ live weight $24 \mathrm{~h}$ and $S=\mu \mathrm{g}$ retinol $/ \mathrm{ro0} \mathrm{ml}$ serum. The regression was highly significant $(P<0.01)$. 
There was no measurable amount of $\beta$-carotene in the serum of the lambs in any group at any sampling period. The amounts of the $\beta$-carotene supplement given to groups G-I resulted in an increase in the serum retinol concentration, whilst the amount given to group $\mathrm{F}$ was sufficient only to maintain the initial concentration.

There was a significant correlation $(P<0.01)$ between the retinol concentration in the serum samples taken just before slaughter and the logarithm of the $\beta$-carotene intake. The regression equation $(n=15)$, was

$$
\begin{aligned}
& S=12 \cdot 4212 \log I_{C}-12 \cdot 49 \\
& \mathrm{RSD}= \pm 5.8 \quad(r=+0.80),
\end{aligned}
$$

where $I_{C}=\mu \mathrm{g} \beta$-carotene intake/kg live weight $24 \mathrm{~h}$ and $S=\mu \mathrm{g}$ retinol/roo ml serum. The regression was highly significant $(P<0 \circ 01)$. The regression equations

Table 3. The relative biological potencies of $\beta$-carotene and retinyl palmitate (expressed as retinol) in maintaining equivalent concentrations of retinol in the blood and liver of the milk-fed lamb as compared with published values for ruminant lambs and young of other

\begin{tabular}{|c|c|c|c|c|}
\hline \multirow{2}{*}{$\begin{array}{c}\text { Amount of } \\
\beta \text {-carotene given } \\
(\mu \mathrm{g} / \mathrm{kg} \mathrm{24} \mathrm{h})\end{array}$} & \multicolumn{4}{|c|}{ Ratio of $\beta$-carotene to retinol } \\
\hline & Plasma* & Liver & Plasma & Liver \\
\hline & \multicolumn{2}{|c|}{ Calves $\uparrow$} & \multicolumn{2}{|c|}{ Pigs $\ddagger$} \\
\hline $88 \cdot 2$ & 4.0 & $5 \cdot 3$ & $5 \cdot 6$ & 3.7 \\
\hline 176 & 6.4 & $7 \cdot 8$ & $7 \cdot 0$ & $5 \cdot I$ \\
\hline 353 & $9 \cdot 6$ & $11 \times 7$ & $8 \cdot 6$ & $6 \cdot 9$ \\
\hline \multirow[t]{2}{*}{705} & $14 \cdot 6$ & $17 \cdot 4$ & 10.7 & $9 \cdot 4$ \\
\hline & \multicolumn{2}{|c|}{ Milk-fed lamb } & \multicolumn{2}{|c|}{ Ruminant lambf } \\
\hline $68 \cdot 5$ & $5 \cdot 4$ & $3 \cdot 1$ & - & - \\
\hline $88 \cdot 2$ & $(6 \cdot 2)$ & $(3 \cdot 6)$ & $6 \cdot 6$ & $5 \cdot 5$ \\
\hline 176 & $(8 \cdot 4)$ & $(5 \cdot 2)$ & $8 \cdot 2$ & $7 \cdot 4$ \\
\hline 275 & 10.2 & $6 \cdot 2$ & - & - \\
\hline 353 & $(I I \cdot 4)$ & $(6 \cdot 8)$ & 10.4 & $10 \cdot 0$ \\
\hline 705 & $(15 \cdot 4)$ & $(7 \cdot 9)$ & $13 \cdot 1$ & 13.4 \\
\hline I 100 & $18 \cdot 7$ & $8 \cdot 4$ & - & - \\
\hline 2200 & $25 \cdot 3$ & 8.9 & - & - \\
\hline
\end{tabular}
species

Values in parentheses were calculated from published reports (see p. 28).

* Serum was used in the milk-fed lamb.

+ Rousseau et al. (1956).

+ Myers et al. (1959).

relating the retinol concentration of the serum samples taken just before slaughter to the logarithm of the retinol concentration in the liver for lambs given either retinyl palmitate $(n=16)$, or $\beta$-carotene $(n=15)$, were

$$
\begin{array}{ll}
\text { Retinyl palmitate } & S=9.4928 \log L+\mathrm{I}_{4} .28 \\
& \mathrm{RSD}= \pm 6.1 \quad(r=+0.87), \\
\beta \text {-carotene } & S=8 \cdot 1577 \log L+\mathrm{II}_{1} \cdot 05 \\
& \mathrm{RSD}= \pm 5.6 \quad(r=+0.85),
\end{array}
$$

where $L=\mu \mathrm{g}$ retinol $/ \mathrm{g}$ liver and $S=\mu \mathrm{g}$ retinol $/ \mathrm{ro0} \mathrm{ml}$ serum. The regressions were highly significant $(P<0.01)$. 
Biological potency. The relative potencies of $\beta$-carotene and retinol for the milk-fed lamb are given in Table 3 , together with comparable values for the biological potency of $\beta$-carotene as determined for calves by Rousseau, Eaton, Teichman, Helmboldt, Jungherr, Bacon \& Beall (1956), and by Myers, Eaton \& Rousseau (1959) for young pigs and lambs. The lambs used by Myers et al. (1959) weighed between I 6 and $32 \mathrm{~kg}$ and were ruminating.

The relative biological potencies of $\beta$-carotene and retinol were calculated from the regression equations ( $1 a),(3)$ and $(5 a),(6)$.

The ratios given in Table 3 suggest that $\beta$-carotene is less efficient, relative to retinol, in raising the retinol concentration in the serum than it is in raising the liver retinol reserves.

We wish to thank Roche Products Pty. Ltd, Sydney, for gifts of retinyl palmitate, $\beta$-carotene and ergocalciferol, and Cyanamid Australia Pty. Ltd for a gift of Aureomycin.

\section{REFERENCES}

Bessey, O. A., Lowry, O. H., Brock, M. J. \& Lopez, J. A. (1946). F. biol. Chem. 166, 177.

Faruque, O. \& Walker, D. M. (1970). Br. F. Nutr. 24, i r.

Hausheer,W., Moor, H., Nobile, S., Mueller, P. B. \& Wagner, H. (1964). In Schweiz. Lebensmittelbuch. Vol. I, 5th ed., p. 655. Bern: Eidg Drucksachen-und Material Centrale.

Myers, G. S. Jr, Eaton, H. D. \& Rousseau, J. E. Jr (1959). F. Anim. Sci. 18, 288.

Rousseau, J. E. Jr, Eaton, H. D., Teichman, R., Helmboldt, C. F., Jungherr, E. L., Bacon, E. L. \& Beall, G. (1956). F. Dairy Sci. 39, ${ }_{5} 55$. 